\title{
Bitter Taste Transduction of Denatonium in the Mudpuppy Necturus maculosus
}

\author{
Tatsuya Ogura, ${ }^{1}$ Alan Mackay-Sim, ${ }^{1,2}$ and Sue C. Kinnamon ${ }^{1}$ \\ 1 Department of Anatomy and Neurobiology, Colorado State University, Fort Collins, Colorado 80523, and Rocky \\ Mountain Taste and Smell Center, University of Colorado Health Sciences Center, Denver, Colorado 80262, and 2School \\ of Biomolecular and Biomedical Science, Griffith University, Nathan, QLD 4111 Australia
}

\begin{abstract}
Bitter substances are a structurally diverse group of compounds that appear to act via several transduction mechanisms. The bitter-tasting denatonium ion has been proposed to act via two different G-protein-regulated pathways, one involving inositol 1,4,5-trisphosphate and raised intracellular calcium levels, the other involving phosphodiesterase and membrane depolarization via a cyclic nucleotide-suppressible cation channel. The aim of the present study was to examine these transduction mechanisms in taste cells of the mudpuppy Necturus maculosus by calcium-imaging and whole-cell recording. Denatonium benzoate increased intracellular calcium levels and induced an outward current independently of extracellular calcium. The denatonium-induced increase in intracellular calcium was inhibited by U73122, an inhibitor of phospholipase C, and
\end{abstract}

by thapsigargin, an inhibitor of calcium transport into intracellular stores. The denatonium-induced outward current was blocked by GDP- $\beta$-S, a blocker of G-protein activation. Neither resting nor denatonium-induced intracellular calcium levels were affected by inhibition of phosphodiesterase (with IBMX) or adenylate cyclase (with SQ22536) or by raising intracellular cyclic nucleotides directly (with cell permeant analogs). Our results support the hypothesis that denatonium is transduced via a G-protein cascade involving phospholipase $\mathrm{C}$, inositol 1,4,5-trisphosphate, and raised intracellular calcium levels. Our results do not support the hypothesis that denatonium is transduced via phosphodiesterase and cAMP.

Key words: bitter taste transduction; mudpuppy; taste receptor cells; fura-2; calcium imaging; whole-cell recording
There are a large number of compounds that taste bitter to humans (Belitz and Weiser, 1985). Given the structural diversity of these compounds, it is expected that there may be multiple transduction mechanisms or multiple receptor proteins in taste receptor cells. Unexpected perhaps is evidence that the bittertasting denatonium ion may operate via two separate transduction pathways. One hypothesis proposes that denatonium activates phospholipase C (PLC), thus increasing intracellular levels of inositol 1,4,5-trisphosphate $\left(\mathrm{IP}_{3}\right)$ to release calcium ions from intracellular stores (Akabas et al., 1988; Hwang et al., 1990; Spielman et al., 1994b). The increase in intracellular calcium is proposed to lead to neurotransmitter release, thereby completing the transduction step (Akabas et al., 1988; Spielman et al., 1994b). Another hypothesis is that denatonium activates phosphodiesterase to decrease intracellular levels of cyclic nucleotides (RuizAvila et al., 1995; Wong et al., 1996), which would depolarize the cell by relieving the cyclic nucleotide block of a membrane cation channel (Kolesnikov and Margolskee, 1995). The influx of cations (including calcium) is proposed to depolarize the cell leading to neurotransmitter release.

These two hypotheses predict several conflicting properties of the responses induced by denatonium. First, although both hypotheses predict a denatonium-induced rise in intracellular calcium, the former predicts that this is attributable to calcium

Received Jan. 22, 1997; revised March 3, 1997; accepted March 5, 1997.

This work was supported in part by National Institutes of Health Grants DC00244 and DC00766 to S.C.K. We thank Dr. Peter Guthrie for his help in establishing our calcium-imaging system and for computer programming, as well as Andrew Bowerman, Vanessa Madsen, and Megan Litster for excellent technical assistance.

Correspondence should be addressed to Dr. Tatsuya Ogura, Department of Anatomy and Neurobiology, Colorado State University, Fort Collins, CO 80523.

Copyright (C) 1997 Society for Neuroscience $0270-6474 / 97 / 173580-08 \$ 05.00 / 0$ release from intracellular stores, whereas the latter predicts that it is attributable to calcium influx from the extracellular medium. Second, although the former hypothesis makes no prediction about the effect of denatonium on the membrane potential, the latter hypothesis predicts that denatonium should depolarize taste cells. Finally, each hypothesis predicts testable pathway-specific effects of pharmacological agents.

In the present report, bitter transduction was studied to test the predictions arising from these two hypotheses. Denatoniuminduced responses were examined in taste cells of mudpuppy Necturus maculosus. Mudpuppies can detect denatonium, and it is aversive to them (Ogura et al., 1996). Mudpuppy taste receptor cells are large, easily isolated, and amenable to study (Kinnamon et al., 1988a), and preliminary experiments indicated that the majority were responsive to denatonium. Denatonium-induced responses of these cells were examined using whole-cell patchclamp recording and calcium imaging using the $\mathrm{Ca}^{2+}$-sensitive dye fura-2.

\section{MATERIALS AND METHODS}

Isolation of taste receptor cells. Mudpuppies (Necturus maculosus) were obtained from commercial suppliers and kept in large aquaria maintained at $10^{\circ} \mathrm{C}$. They were fed live minnows weekly. Taste receptor cells were isolated from mudpuppies, as described previously (Kinnamon et al., 1988a). Briefly, mudpuppies were anesthetized by immersion in ice water and decapitated. The lingual epithelium was dissected from the underlying connective tissue. To distinguish mature taste cells from other cell types, they were labeled at the apical membrane by incubating the epithelium for $15 \mathrm{~min}$ in fluorescein isothiocyanate-conjugated wheat germ agglutinin [FITC-WGA, $0.5 \mathrm{mg} / \mathrm{ml}$ in amphibian physiological saline (APS)] (Kinnamon et al., 1988b). The epithelium was then incubated in APS that contained collagenase $(1 \mathrm{mg} / \mathrm{ml}$, Worthington Biochemical, Freehold, NJ), albumin $(1 \mathrm{mg} / \mathrm{ml})$, and glucose $(5 \mathrm{~mm})$, until the mucosal layers of the nongustatory epithelium could be gently peeled free from 

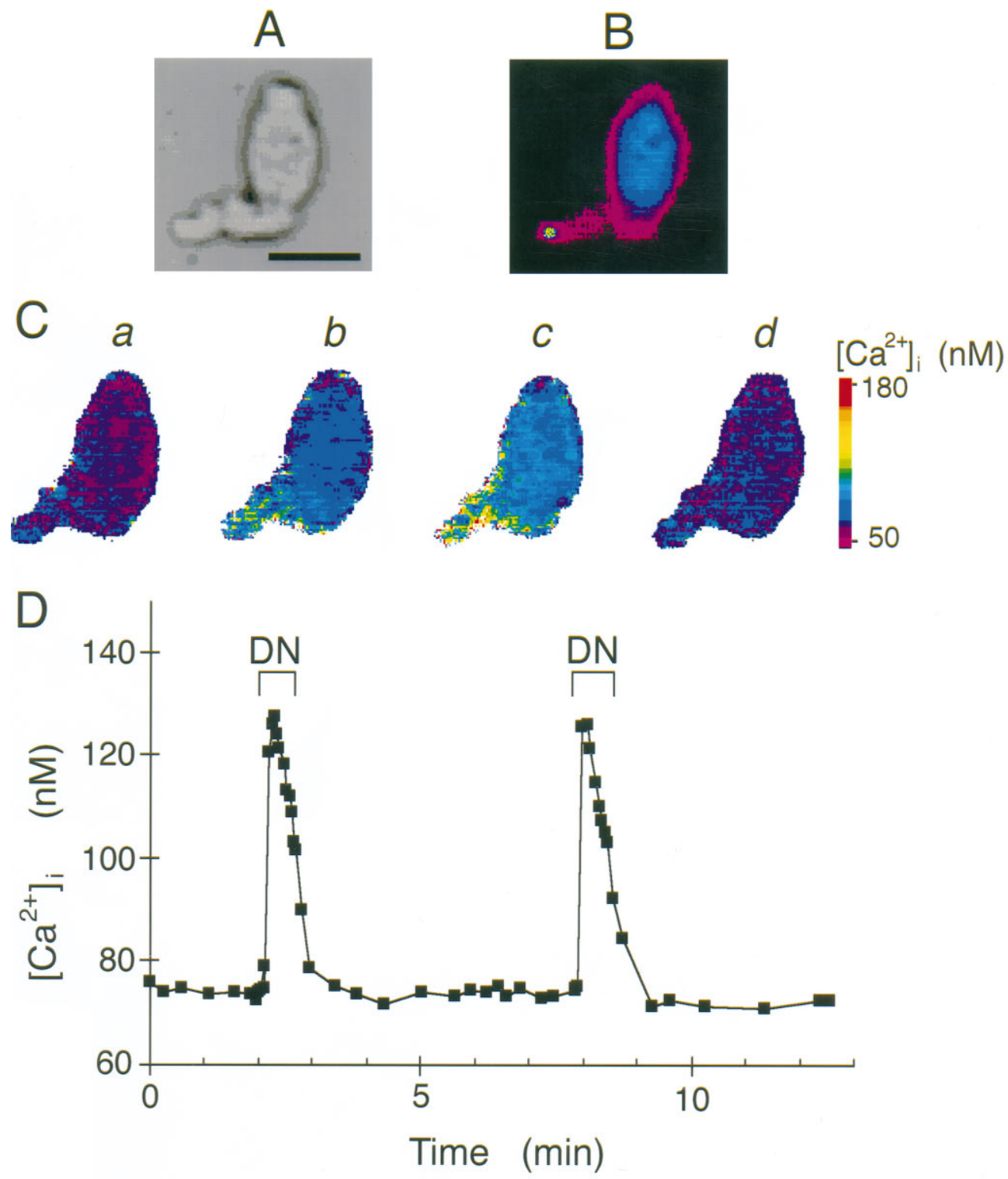

Figure 1. Denatonium increased intracellular calcium levels. $A$, Light image of an isolated taste cell. Scale bar, $20 \mu \mathrm{m}$. $B$, Fluorescence image of the same cell showing the apical tip of the taste cell labeled with FITC-WGA. The labeled region is shown in white in this pseudocolor image. $C$, Calcium images of the same taste cell loaded with the $\mathrm{Ca}^{2+}$-sensitive dye fura-2. The pseudocolor scale of $\left[\mathrm{Ca}^{2+}\right]_{\mathrm{i}}$ is shown on the right. $a,\left[\mathrm{Ca}^{2+}\right]_{\mathrm{i}}$ before and $b, \mathrm{im}$ mediately after application of $5 \mathrm{~mm}$ denatonium benzoate. The increase in $\left[\mathrm{Ca}^{2+}\right]_{\mathrm{i}}$ begins at the apical tip. $c,\left[\mathrm{Ca}^{2+}\right], 30 \mathrm{sec}$ after application of denatonium benzoate. $\left[\mathrm{Ca}^{2+}\right]_{i}$ increases over entire cell. $d$, $\left[\mathrm{Ca}^{2+}\right]_{\mathrm{i}}$ after washing the cells for $2 \mathrm{~min}$ with APS. $\left[\mathrm{Ca}^{2+}\right]_{\mathrm{i}}$ returns to resting level. $D$, Typical time course of denatoniuminduced calcium responses. Denatonium benzoate $(5 \mathrm{~mm})$ was applied during the periods labeled $D N$. Note that the denatonium-induced responses are similar after repeated application of denatonium.

the underlying lamina propria, which left the taste buds attached to their papillae. The remaining tissue was treated with $\mathrm{Ca}^{2+}$-free APS to dissociate the taste buds. Isolated cells were plated in recording chambers made with coverslips (for calcium imaging) or slides (for whole-cell recording) coated with Cell-Tak (Collaborative Research, Bedford, MA).

Intracellular $\left[\mathrm{Ca}^{2+}\right]$ measurement. Isolated cells in the chamber were loaded with the cell-permeable, $\mathrm{Ca}^{2+}$-sensitive, fluorescent dye fura-2 AM (5 $\mu$ M, Molecular Probes, Eugene, OR) for $30 \mathrm{~min}$, then washed with normal APS for $20 \mathrm{~min}$. Images were acquired with an intensified CCD camera (IC100-ICCD, Paultek Imaging, Grass Valley, CA) through an oil-immersion objective lens (Fluor 40×, 1.3 NA, Nikon) of an inverted microscope (Diaphot TMD, Nikon). The video signal from the camera was captured with a frame grabber board (Quick Capture, Data Translation) on an Macintosh computer (Quadra 800, Apple Computer). For dual-wavelength ratiometric $\mathrm{Ca}^{2+}$ measurements, pairs of fluorescent images were recorded at 350 and $380 \mathrm{~nm}$ of excitation light using a filter wheel (EMPIX Imaging). Emitted light was collected by a $510-580 \mathrm{~nm}$ bandpass filter (Chroma Technology). In our system, space resolution is $\sim 3000$ pixels/cell. Pseudocolor $\mathrm{Ca}^{2+}$ images (e.g., Fig. $1 C$ ) were generated as 20 level color images from ratios of 350 and $380 \mathrm{~nm}$ images using the public domain National Institutes of Health (NIH) Image program (developed at NIH and available on the Internet at http://rsb.info.nih.gov/ nih-image/). Intracellular $\mathrm{Ca}^{2+}$ concentration $\left(\left[\mathrm{Ca}^{2+}\right]_{\mathrm{i}}\right)$ in selected areas was calculated from the ratio of 350 and $380 \mathrm{~nm}$ images (Grynkiewicz et al., 1985). $\mathrm{Ca}^{2+}$ calibration curves were obtained with calcium calibration kit II (C-3009, Molecular Probes). For plotting the time course of $\left[\mathrm{Ca}^{2+}\right]_{\mathrm{i}}$ (e.g., Fig. 2), we averaged the $\left[\mathrm{Ca}^{2+}\right]_{\mathrm{i}}$ over most of the cell area, avoiding the edges of the cell. With a recording chamber volume of $\sim 200 \mu \mathrm{l},<10$ $\mathrm{sec}$ was required to totally exchange solutions by superfusion.

Cells were bathed in normal APS until the resting intracellular calcium level was stable. The bath was then perfused with APS containing denatonium benzoate ( $5 \mathrm{~mm}$, Sigma, St. Louis, MO). This was followed by washing with normal APS until the intracellular calcium again reached prestimulus levels. Cells were then perfused with other APS solutions including $\mathrm{Ca}^{2+}$-free APS, ryanodine $(10 \mu \mathrm{M}$ for $2-5 \mathrm{~min}$ or $200 \mu \mathrm{M}$ for 10 min, Calbiochem, La Jolla, CA), thapsigargin (1 $\mu \mathrm{M}$ for $12-16 \mathrm{~min}$, Sigma), U73122 (5 $\mu \mathrm{M}$ for 12-17 min, Calbiochem), isobutyl methoxyxanthine (IBMX, 100 or $200 \mu \mathrm{M}$ for 1-3 min, Sigma), SQ22536 (2.5 mM for 30-40 min, Calbiochem); dibutyryl-cAMP (db-cAMP, $5 \mathrm{~mm}$ for 1-3 min, Sigma); dibutyryl-cGMP (db-cGMP, $5 \mathrm{~mm}$ for 1-3 min, Sigma), and a mixture of db-cGMP (2 mM for 1-3 min, Sigma) and 8-chlorophenylthiocAMP (8-cpt-cAMP, $2 \mathrm{~mm}$ for 1-3 min, Sigma). Some cells were incubated in pertussis toxin (PTX, 0.5 or $2 \mu \mathrm{g} / \mathrm{ml}$ in APS, Sigma) for $>20 \mathrm{hr}$ at $4^{\circ} \mathrm{C}$.

Cells were considered to respond to denatonium if it caused an increase in $\left[\mathrm{Ca}^{2+}\right]_{i}$, which was $>2 \mathrm{SD}$ values above the mean resting level of each cell. The effects of drug treatments on the denatonium response were assessed using Student's $t$ tests. Statistical values are presented as mean $\left[\mathrm{Ca}^{2+}\right]_{\mathrm{i}} \pm$ SEM.

Giga-seal whole-cell recording. Membrane currents were measured us- 

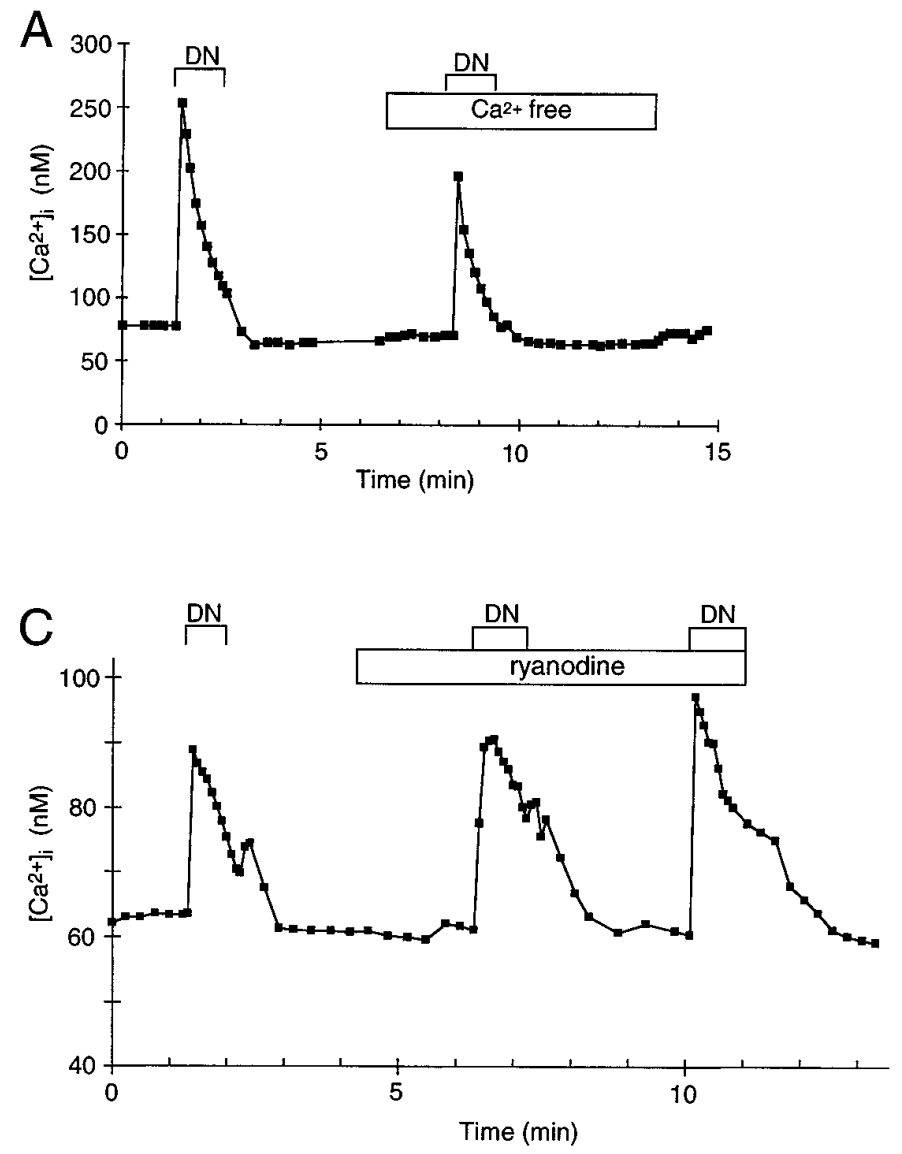
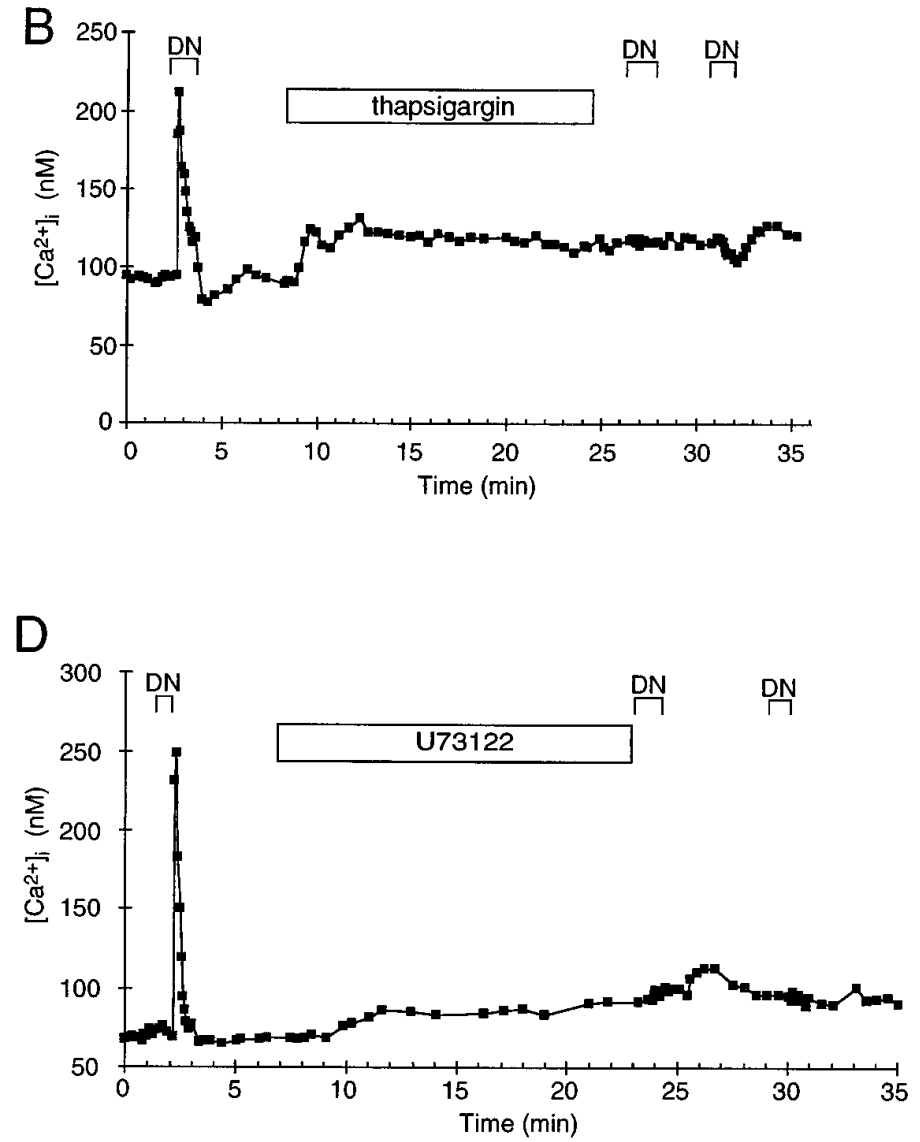

Figure 2. Time courses of changes in $\left[\mathrm{Ca}^{2+}\right]_{\mathrm{i}}$. Measurements of $\left[\mathrm{Ca}^{2+}\right]_{\mathrm{i}}$ in individual cells using fura-2. Denatonium benzoate (5 mM) was applied during the periods labeled $D N$. $A$, The denatonium-induced calcium response was present in $\mathrm{Ca}^{2+}$-free extracellular solution. $B$, Thapsigargin $(1 \mu \mathrm{M})$ abolished the denatonium-induced calcium response. $C$, The denatonium-induced calcium response was not affected by ryanodine $(10 \mu \mathrm{M})$. $D$, The denatoniuminduced calcium response was abolished by the PLC inhibitor U73122 $(5 \mu \mathrm{M})$.

ing giga-seal whole-cell recording (Hamill et al., 1981). Electrodes were fabricated from microhematocrit capillary tubes (American Scientific Products, McGaw Park, IL) pulled on a two-stage vertical puller (Narishige). When filled with intracellular saline, resistances ranged from 1.8 to $3.5 \mathrm{M} \Omega$. Cells were viewed at a magnification of $400 \times$, using a Nikon Diaphot inverted microscope fitted with Hoffman optics. Seals of 1-10 $\mathrm{G} \Omega$ were obtained by gentle suction, and whole-cell recordings were achieved by delivery of a short depolarizing pulse to the pipette. Wholecell currents were measured at room temperature using an Axopatch 1D patch-clamp amplifier (Axon Instruments, Foster City, CA). Signals were prefiltered at $5 \mathrm{kHz}$ (low-pass filter) and recorded digitally at $100 \mu \mathrm{sec}$ intervals unless otherwise specified. Data were stored using a laboratory computer (11/23, Digital Equipment, Maynard, MA) equipped with a Cheshire data interface and Basic 23 software (Indec Systems). The computer also generated all voltage commands. In some experiments, data were also stored on a Pentium computer (Applied Computer Technology), using Axoscope software (Axon Instruments). Unless otherwise noted, leak and linear capacitative currents were subtracted from all records by computer. Series resistance, which was typically $<10 \mathrm{M} \Omega$, was not compensated. Gravity-fed stimuli were bath-applied to the $0.5 \mathrm{ml}$ recording chamber. To prevent loss of the seal and to prevent perfusion artifacts during whole-cell recording, the perfusion rate was lowered to $2-3 \mathrm{ml} / \mathrm{min}$. To ensure that data were obtained from viable taste receptor cells, only cells exhibiting voltage-gated $\mathrm{Na}^{+}$currents and input resistances $>0.5 \mathrm{G} \Omega$ were selected for data analysis.

After whole-cell recording was obtained and membrane capacitance was electronically compensated, membrane currents were measured in normal APS by stepping the cell membrane from -60 to $80 \mathrm{mV}$ in $10 \mathrm{mV}$ increments. The bath was then perfused with $1 \mathrm{~mm}$ denatonium benzoate, and membrane currents were again measured. Finally, the denatonium was washed out of the bath with normal APS and the currents again measured. In some cells, the tip of the pipette was filled with the normal pipette solution but backfilled with a solution containing $1 \mathrm{~mm}$ GDP- $\beta$-S (Sigma). In some experiments, $1 \mu \mathrm{M}$ tetrodotoxin (TTX, Sigma) was added to the bath to block $\mathrm{Na}^{+}$currents. There was no effect of TTX on the response to denatonium.

For comparison, control and denatonium-induced currents were measured at $35 \mathrm{msec}$ after the membrane potential was stepped to $+80 \mathrm{mV}$. Statistical values are presented as mean currents \pm SEM.

Solutions. Normal APS contained (in mM): $112 \mathrm{NaCl}, 2 \mathrm{KCl}, 8 \mathrm{CaCl}_{2}$, 3 HEPES, buffered to pH 7.2 with $\mathrm{NaOH}$. $\mathrm{Ca}^{2+}$-free APS contained either $1 \mathrm{~mm}$ BAPTA (for cell isolation) or $1 \mathrm{~mm}$ EGTA (for calcium imaging). Patch pipette solution contained (in $\mathrm{mM}$ ): $114 \mathrm{KCl}, 2 \mathrm{NaCl}, 0.09$ $\mathrm{CaCl}_{2}, 2 \mathrm{MgCl}_{2}, 1$ BAPTA, 1 ATP, $0.4 \mathrm{GTP}, 10$ HEPES, buffered to $\mathrm{pH}$ 7.2 with $\mathrm{KOH}$.

\section{RESULTS}

\section{Denatonium increased intracellular calcium levels}

We measured $\left[\mathrm{Ca}^{2+}\right]_{\mathrm{i}}$ in isolated mudpuppy taste cells using calcium imaging with the $\mathrm{Ca}^{2+}$-sensitive fluorescent dye fura-2. Mature taste cells were identified by their elongate shape and apical fluorescence of the FITC-WGA applied to the epithelium before dissociation (Fig. 1 $A, B$ ). Under control conditions, isolated taste cells had intracellular calcium levels of $71 \pm 1 \mathrm{~nm}(n=$ 203). Denatonium benzoate increased $\left[\mathrm{Ca}^{2+}\right]_{i}$ in $>80 \%$ of the taste cells tested. The increase in $\left[\mathrm{Ca}^{2+}\right]_{\mathrm{i}}$ occurred initially at the apical tip of the taste cell, then spread basolaterally until $\left[\mathrm{Ca}^{2+}\right]_{i}$ was increased over the entire cell (Fig. 1C). The initial response occurred in the apical end, even though the denatonium was bath-applied to the entire cell. The time course of the response is 


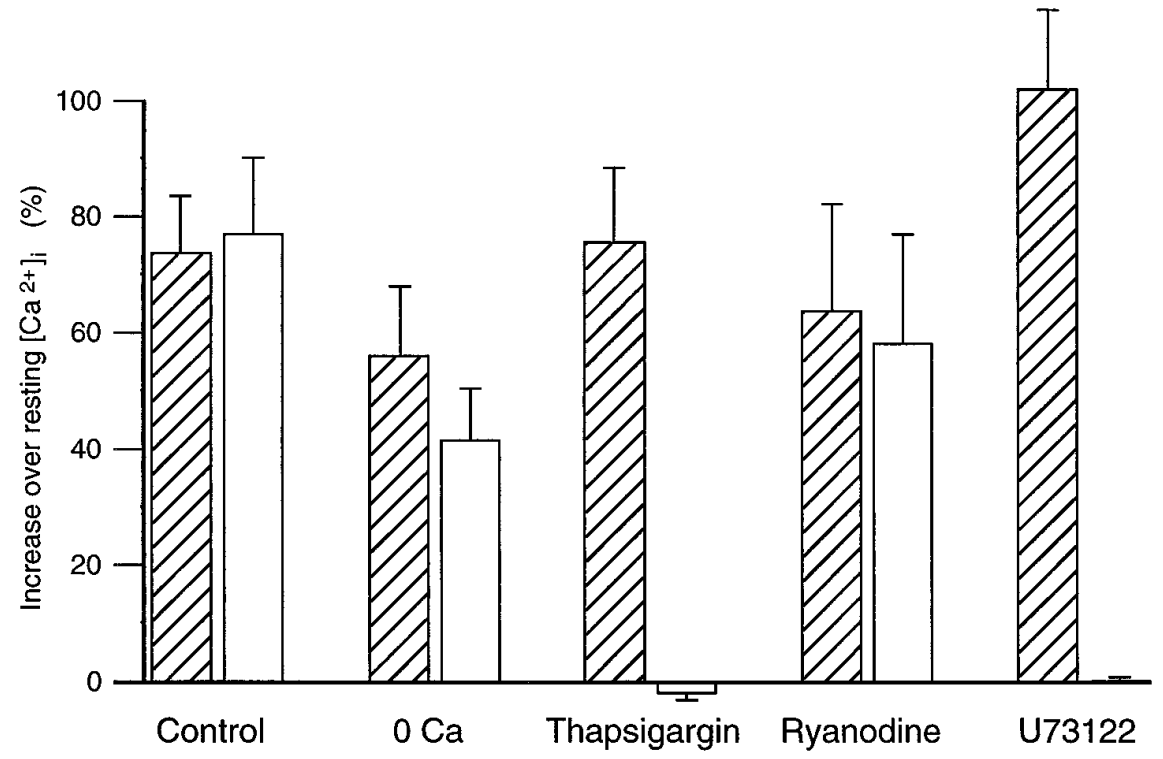

Figure 3. Denatonium-induced changes in $\left[\mathrm{Ca}^{2+}\right]_{\mathrm{i}}$ depended on intracellular stores. This graph shows maximum denatonium-induced changes in $\left[\mathrm{Ca}^{2+}\right]_{\mathrm{i}}$ expressed as a percentage of resting $\left[\mathrm{Ca}^{2+}\right]_{\mathrm{i}}$. Cells were tested twice, before (hatched bars) and during or after (open bars) the treatments indicated, as illustrated in Figure $2\left[\mathrm{Ca}^{2+}\right.$-free bath solution $(0 \mathrm{Ca}$; $n=17)$, thapsigargin $(n=34)$, ryanodine $(n=12)$, and $\operatorname{U73122}(n=18)]$. Control cells were tested twice, as illustrated in Figure $1 D(n=16)$, the first and second stimulations indicated by the hatched and open bars, respectively. shown in Figure $1 D$. The peak response occurred near the first measurement, which was $\sim 5 \mathrm{sec}$ after application of denatonium to the recording chamber. Intracellular $\mathrm{Ca}^{2+}$ levels began to decline in the presence of denatonium and then decreased further to baseline levels after the denatonium was washed from the chamber (Figs. $1 D, 2$ ). The peak $\left[\mathrm{Ca}^{2+}\right]_{\mathrm{i}}$ elicited by $5 \mathrm{~mm}$ denatonium benzoate was usually $50-150 \%$ of the resting $\left[\mathrm{Ca}^{2+}\right]_{i}$ (133 $\pm 4 \mathrm{nM}, n=203)$. Repeated applications of denatonium to the same cell resulted in similar increases in $\left[\mathrm{Ca}^{2+}\right]_{i}$, as long as the cell was washed for at least $3 \mathrm{~min}$ after each application of denatonium (first application, $130 \pm 12 \mathrm{~nm}$; second application, $133 \pm 14 \mathrm{nM}, n=16)$ (Figs. $1 D, 3)$. Sodium benzoate $(5 \mathrm{~mm})$ failed to increase $\left[\mathrm{Ca}^{2+}\right]_{\mathrm{i}}$ in five taste cells that responded to denatonium benzoate $(5 \mathrm{~mm})$, suggesting that benzoate itself has no effect on the taste cells. We also measured $\left[\mathrm{Ca}^{2+}\right]_{\mathrm{i}}$ in nontaste lingual epithelial cells; denatonium failed to increase $\left[\mathrm{Ca}^{2+}\right]_{\mathrm{i}}$ in any of these cells.

\section{Calcium was released from intracellular stores}

To determine whether extracellular $\mathrm{Ca}^{2+}$ was required, we measured $\left[\mathrm{Ca}^{2+}\right]_{\mathrm{i}}$ in response to denatonium in $\mathrm{Ca}^{2+}$-free APS. In this medium, the resting $\left[\mathrm{Ca}^{2+}\right]_{\mathrm{i}}$ was reduced (initial level, $73 \pm 6 \mathrm{nM}$; $\mathrm{Ca}^{2+}$-free APS, $65 \pm 2 \mathrm{nM} ; n=17$ ), but not significantly (paired, one-tailed Student's $t$ test $=1.52$, df $=16, p=0.07$ ). The denatonium response persisted in all taste cells tested, although the magnitude of the response was usually smaller than in $\mathrm{Ca}^{2+}$. containing APS (Figs. $2 A, 3$ ). This reduction in the denatonium response was statistically significant (paired Student's $t$ test $=$ $2.37, \mathrm{df}=16, p<0.05)$. These data illustrate that the response to denatonium persisted in $\mathrm{Ca}^{2+}$-free APS and suggest that at least the major part was mediated by calcium release from intracellular stores. To investigate the role of calcium stores in the response, we used thapsigargin, a $\mathrm{Ca}^{2+}$-ATPase inhibitor. Thapsigargin prevents calcium uptake into the intracellular stores (Chu et al., 1988; Meyer and Stryer, 1990; Thastrup et al., 1990). This results in a gradual depletion of calcium from the intracellular stores as the calcium leaks out and is not replenished. We tested the effect of thapsigargin on 34 cells that responded to denatonium. Thapsigargin $(1 \mu \mathrm{M})$ increased $\left[\mathrm{Ca}^{2+}\right]_{\mathrm{i}}$ to a variable extent in all of these cells. This increase in $\left[\mathrm{Ca}^{2+}\right]_{i}$ was slow, and the peak $\left[\mathrm{Ca}^{2+}\right]_{i}$ was smaller than the denatonium responses in most cells tested (initial level, $79 \pm 4 \mathrm{nM}$; after thapsigargin, $108 \pm 7 \mathrm{nM} ; n=34$ ). After a $16 \mathrm{~min}$ incubation with thapsigargin, which should be sufficient for store depletion, $5 \mathrm{~mm}$ denatonium failed to increase $\left[\mathrm{Ca}^{2+}\right]_{\mathrm{i}}$ in 27 of 29 cells tested (Figs. $2 \mathrm{~B}, 3$ ). This effect of thapsigargin on the response to denatonium was statistically significant (paired Student's $t$ test $=5.40$, df $=26, p<0.0001$ ). These data strongly suggest that denatonium releases calcium from internal stores and not from extracellular influx, because thapsigargin inhibited completely the denatonium response. Thus, the decrease in the response to denatonium in $\mathrm{Ca}^{2+}$-free APS may be attributable to a requirement of extracellular $\mathrm{Ca}^{2+}$ for reloading of the intracellular stores, as has been shown in neurons (Thayer et al., 1988).

\section{Calcium was released from $\mathrm{IP}_{\mathbf{3}}$-sensitive stores}

Two different types of calcium stores have been identified: one coupled to an inositol $\mathrm{IP}_{3}$ receptor and another coupled to a ryanodine-sensitive calcium receptor (Sharp et al., 1993; Simpson et al., 1995). To investigate which intracellular calcium receptors are involved in the denatonium response, we applied denatonium in the presence of $10 \mu \mathrm{M}$ ryanodine. Ryanodine did not change resting $\left[\mathrm{Ca}^{2+}\right]_{\mathrm{i}}$ (initial level, $77 \pm 6 \mathrm{nM}$; after ryanodine, $79 \pm 6$ $\mathrm{nM} ; n=12)$ and did not affect the $\left[\mathrm{Ca}^{2+}\right]_{\mathrm{i}}$ increase in response to denatonium (Figs. $2 C, 3)(125 \pm 22 \mathrm{~nm} ; n=12)$. High concentrations of ryanodine have been shown to inhibit $\mathrm{Ca}^{2+}$ release from ryanodine receptor-coupled calcium stores (Sutko et al., 1985). To determine whether higher concentrations of ryanodine would inhibit the denatonium response, we incubated taste cells in $200 \mu \mathrm{M}$ ryanodine for $11 \mathrm{~min}$, but there was no significant effect on the denatonium response. Thus, ryanodine receptor-coupled calcium stores are not likely to be involved in the response to denatonium. To determine whether calcium stores in taste cells are $\mathrm{IP}_{3}$ receptor-coupled, we used the PLC inhibitor U73122, because $\mathrm{IP}_{3}$ is produced via the PLC pathway (Thompson et al., 1991; Salari et al., 1993). U73122 (5 $\mu \mathrm{M})$ increased $\left[\mathrm{Ca}^{2+}\right]_{\mathrm{i}}$ in all cells (initial level, $78 \pm 5 \mathrm{nM}$; U73122, $97 \pm 6 \mathrm{nM} ; n=18$ ). The increase of $\left[\mathrm{Ca}^{2+}\right]_{\mathrm{i}}$ by U73122 itself might be mediated by calcium release from $\mathrm{IP}_{3}$ receptor-coupled calcium stores, as shown in rat liver microsomes (De Moel et al., 1995). After a $17 \mathrm{~min}$ incubation with U73122, calcium responses induced by denatonium were inhibited (Figs. 2D, 3). This effect of U73122 on the response to 


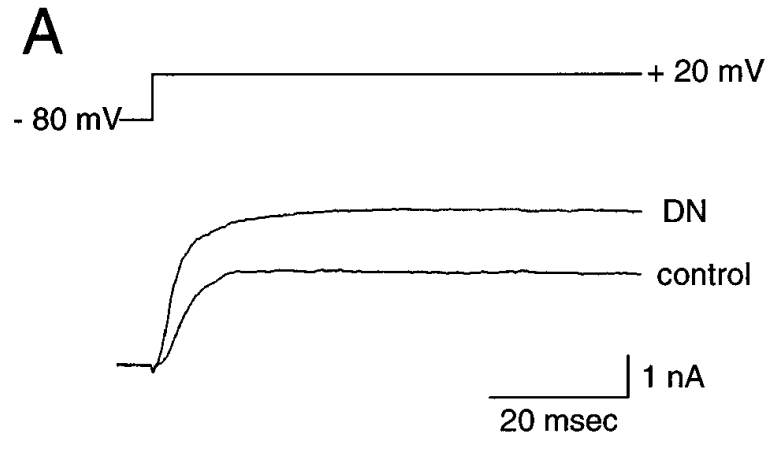

B

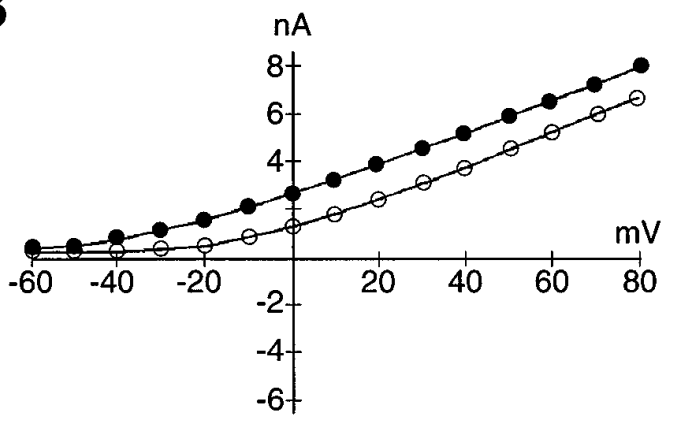

Figure 4. Electrophysiological response of a mudpuppy taste cell to denatonium. The bath contained TTX to block inward $\mathrm{Na}^{+}$currents. $A$, Whole-cell recording under control conditions and in response to $1 \mathrm{~mm}$ denatonium benzoate $(D N)$. The cell was held at $-80 \mathrm{mV}$, and the membrane was stepped to $+20 \mathrm{mV}$ to elicit outward current. Leak and linear capacitative currents were subtracted from the record by computer. $B$, Current-voltage relationship of the denatonium response in the same cell, as shown in $A$. Notice that denatonium increased outward currents at most voltages (solid circles).

denatonium was statistically significant (paired Student's $t$ test $=$ 7.37, df $=17, p<0.0001)$. These results strongly suggest that $\mathrm{IP}_{3}$ is involved in the response of mudpuppy taste cells to denatonium.

\section{Denatonium hyperpolarizes mudpuppy taste cells}

We also used giga-seal whole-cell recording to study denatonium transduction in isolated taste cells. Isolated mudpuppy taste cells have resting potentials of approximately $-65 \mathrm{mV}$ and input resistances of $\sim 1.4 \mathrm{G} \Omega$ (Kinnamon and Roper, 1988). Under voltage-clamp conditions, we measured voltage-activated current in response to $1 \mathrm{~mm}$ denatonium. Denatonium increased outward currents in 20 of 25 cells elicited by step depolarizations from a holding potential of $-80 \mathrm{mV}$ (Fig. $4 A$ ). The increase in outward current was observed at all potentials positive to $-40 \mathrm{mV}$ (Fig. $4 B$ ). The outward current induced by denatonium was close to $50 \%$ greater than the current recorded in APS (APS before, $2.7 \pm$ $0.3 \mathrm{nA} ; 1 \mathrm{~mm}$ denatonium benzoate, $4.0 \pm 0.5 \mathrm{nA}$; APS after, $3.4 \pm 0.7 \mathrm{nA} ; n=11$ ). The time course of the effect is shown in Figure 5. The time course of the current response was similar to the time course of the $\mathrm{Ca}^{2+}$ response (e.g., Figs. 1, 2), suggesting that the current response was produced by an increase in $\left[\mathrm{Ca}^{2+}\right]_{i}$ in response to denatonium. Indeed, $\mathrm{Ca}^{2+}$-dependent $\mathrm{K}^{+}$(Cummings and Kinnamon, 1992) and $\mathrm{Cl}^{-}$(Taylor and Roper, 1994) conductances have been identified in mudpuppy taste cells, and activation of these conductances would elicit an increase in outward current under our recording conditions. The current increased, then began decreasing, in the continued presence of

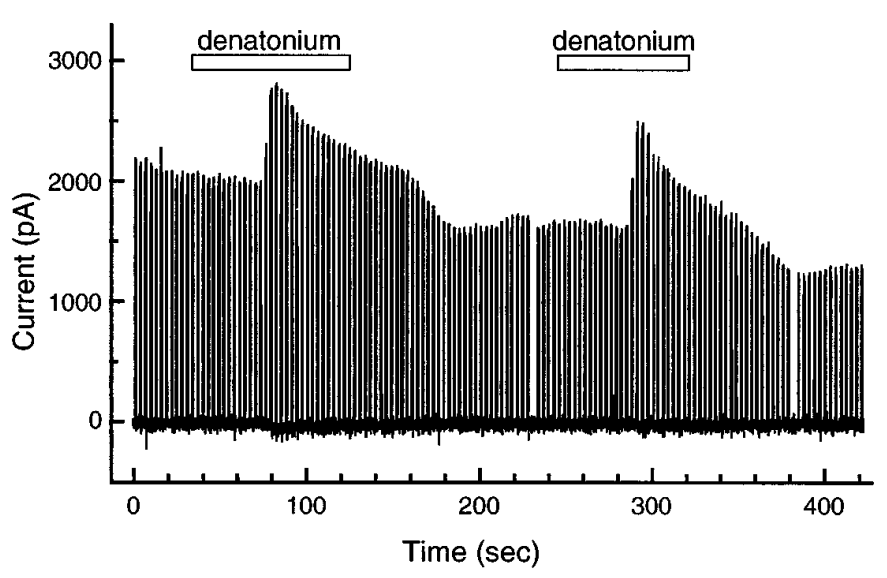

Figure 5. Time course of the electrophysiological response to denatonium. The cell was held at $-80 \mathrm{mV}$, and the membrane was stepped to $+20 \mathrm{mV}$ for $175 \mathrm{msec}$ every $3 \mathrm{sec}$. Data were digitized at $125 \mathrm{~Hz}$ and plotted with Axoscope software. TTX was present in the bath solution to block $\mathrm{Na}^{+}$currents. Note that $1 \mathrm{~mm}$ denatonium elicited an increase in outward current, which is similar in kinetics to the $\left[\mathrm{Ca}^{2+}\right]_{i}$ response shown in Figures 1 and 2.

denatonium. To confirm that the denatonium-induced increase in outward current would hyperpolarize the cells, we used currentclamp recording. As expected, the increase in outward current was accompanied by a 3-10 $\mathrm{mV}$ hyperpolarization of the resting potential ( $n=2$ cells).

In some experiments, denatonium was applied focally to taste cells with a picospritzer during whole-cell recording. Under these conditions, denatonium activated an outward current that was similar to the current that was activated by bath application of denatonium (data not shown).

\section{G-protein involvement in the response to denatonium}

To investigate the involvement of G-proteins in the denatonium response, we used patch pipettes containing a nonhydrolyzable GDP analog, GDP- $\beta$-S (1 mM) (Burch and Axelrod 1987; Gilman, 1987). Six minutes after the establishment of the whole-cell configuration, denatonium still increased the outward current elicited by a voltage step to $+80 \mathrm{mV}$ (Fig. 6A). By $15 \mathrm{~min}$, however, denatonium failed to increase outward currents (Fig. 6B). Three other cells showed similar results. Control cells held for similar periods did not show an appreciable decline in the response to denatonium, making it unlikely that the decline with GDP- $\beta$-S was attributable either to rundown or to desensitization. These results suggest that G-proteins are required for transduction of denatonium.

To determine which type of G-protein is involved in the pathway, we incubated lingual epithelia in PTX, which inhibits $G_{i}, G_{0}$, gustducin, and transducin by ADP ribosylation of the G-protein $\alpha$ subunit (Birnbaumer, 1990; Simon et al., 1991). Dissected lingual epithelia were treated with PTX $(0.5$ and $2 \mu \mathrm{g} / \mathrm{ml}$ in APS $)$ for $>20$ hr at $4^{\circ} \mathrm{C}$. Incubation with PTX affected neither the resting levels of intracellular calcium (control group, $74 \pm 2 \mathrm{nM}, n=13$; PTX-treated group, $73 \pm 3 \mathrm{~nm}, n=24$ ) nor the response to denatonium (Fig. 7).

\section{cAMP involvement in the response to denatonium}

The involvement of cAMP in the denatonium response was examined by increasing intracellular cyclic nucleotides (using IBMX, a phosphodiesterase inhibitor, and cell permeant cAMP and cGMP analogs) and by decreasing intracellular cyclic nucle- 


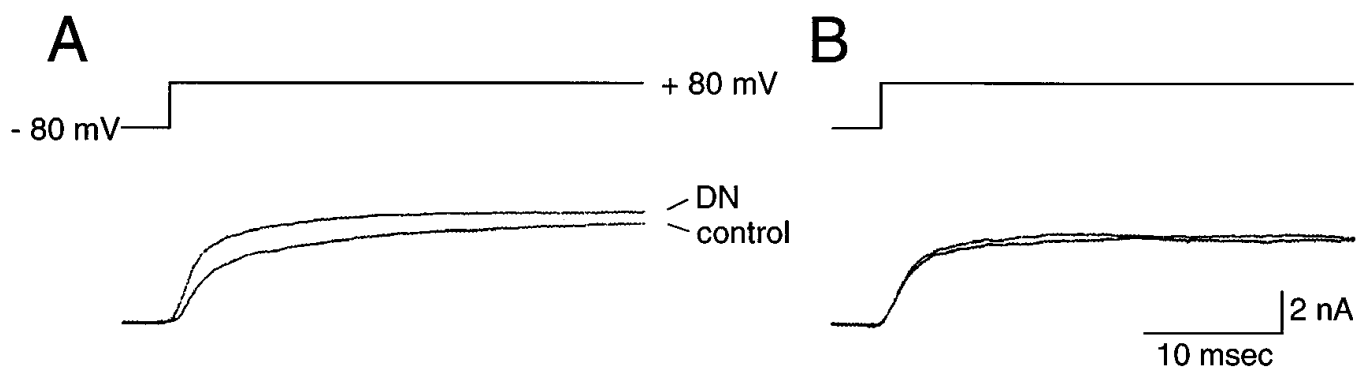

Figure 6. Effect of GDP- $\beta$-S on the denatonium-induced outward current. This cell was held at $-80 \mathrm{mV}$, and the membrane was stepped to $+80 \mathrm{mV}$. TTX was present in the bath solution to block $\mathrm{Na}^{+}$currents. $A$, After 6 min of whole-cell recording and $B$, after 15 min of whole-cell recording. Note that the GDP- $\beta$-S (1 mM in pipette solution) abolished the denatonium response, suggesting that the response was G-protein-dependent.

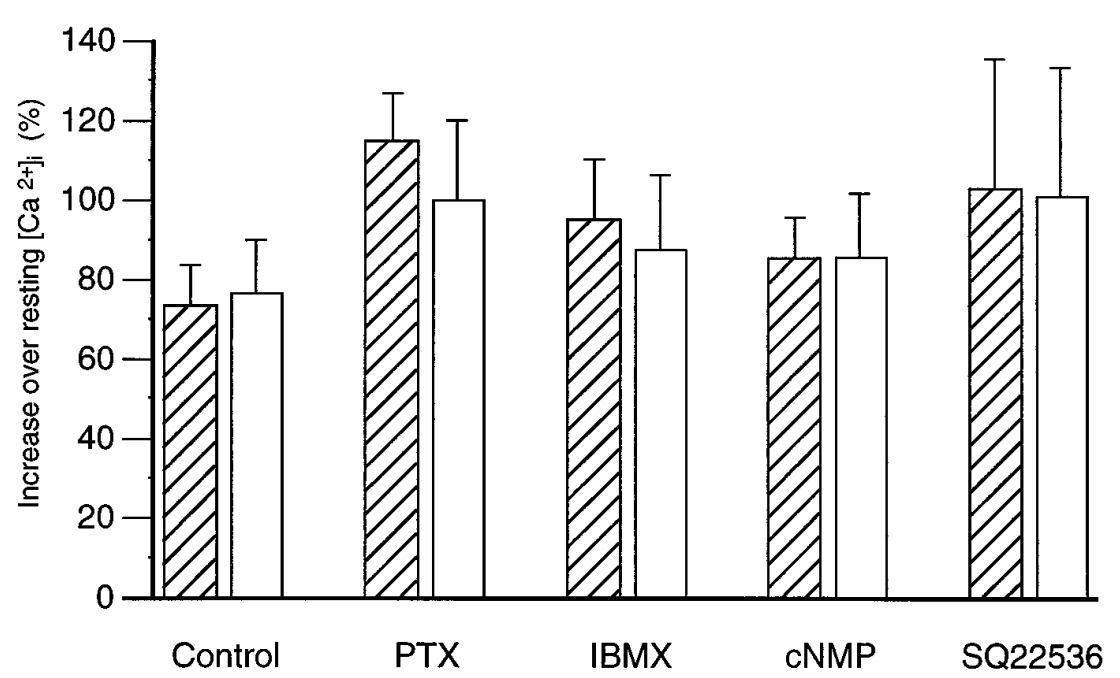

Figure 7. Denatonium-induced changes in $\left[\mathrm{Ca}^{2+}\right]_{\mathrm{i}}$ did not depend on intracellular cAMP. This graph shows maximum denatonium-induced changes in $\left[\mathrm{Ca}^{2+}\right]_{\mathrm{i}}$ expressed as a percentage of resting $\left[\mathrm{Ca}^{2+}\right]_{\mathrm{i}}$. Control cells are those illustrated in Figure 3. PTX cells represent two groups of cells: a control group incubated overnight in APS (hatched bar, $n=13$ ) and a treatment group incubated overnight in PTX (open bar, $n=24$ ). Other cells were tested twice before (hatched bars) and during or after (open bars) the treatments indicated: $\operatorname{IBMX}(n=$ 17); cell permeant cyclic nucleotides (cNMP: db-cAMP, $n=4$; db-cGMP, $n=6$; 8-cpt-cAMP + db-cGMP, $n=$ $3)$, and SQ22536 $(n=3)$. otides (using SQ22536, an inhibitor of adenylate cyclase) (Harris et al., 1979; Goldsmith and Abrams, 1991). Incubation with IBMX did not affect resting $\left[\mathrm{Ca}^{2+}\right]_{\mathrm{i}}$ (initial level, $68 \pm 3 \mathrm{nM}$; after IBMX, $64 \pm 3 \mathrm{nM} ; n=17)$. Although IBMX reduced the response to denatonium in some cells, it had no effect on the mean response (Fig. 7). Incubation with cyclic nucleotides did not affect resting $\left[\mathrm{Ca}^{2+}\right]_{\mathrm{i}}[\mathrm{db}-\mathrm{cAMP}(5 \mathrm{mM})$ before, $66 \pm 5 \mathrm{nM}$ and after, $64 \pm 4 \mathrm{nM}$; $n=7$; db-cGMP (5 mM) before, $62 \pm 7 \mathrm{nM}$ and after, $60 \pm 7 \mathrm{nM}$, $n=7$; 8-cpt-cAMP (2 mM) + db-cGMP ( $2 \mathrm{mM})$ before, $67 \pm 2 \mathrm{nM}$ and after, $65 \pm 7 \mathrm{nM}, n=3$ ]. None of the cyclic nucleotides affected the denatonium-induced calcium response. (Responses are grouped together and shown in Fig 7.) Incubation of the cells with SQ22536 (2.5 $\mathrm{mm}$ for 30 or $40 \mathrm{~min}$ ) did not affect resting $\left[\mathrm{Ca}^{2+}\right]_{\mathrm{i}}$ (initial level, $54 \pm 4 \mathrm{nM}$; after SQ22536, $55 \pm 2 \mathrm{nM}$; $n=3$ ) and did not affect the denatonium-induced calcium response (Fig. 7).

\section{DISCUSSION}

In this study, we used calcium-imaging and whole-cell patch recording to examine the transduction of denatonium in isolated mudpuppy taste cells. The results support the hypothesis that denatonium increases $\left[\mathrm{Ca}^{2+}\right]_{\mathrm{i}}$ via a G-protein cascade involving PLC and $\mathrm{IP}_{3}$ (Hwang et al., 1990; Spielman et al., 1994b). Our evidence does not support the hypothesis that denatonium is transduced via a pathway involving phosphodiesterase and membrane depolarization via a cyclic nucleotide-suppressible cation channel (Kolesnikov and Margolskee, 1995; Wong et al., 1996).

The $\mathrm{IP}_{3}$-mediated hypothesis is supported by a number of observations. First, denatonium benzoate increased intracellular calcium via calcium release from intracellular stores and not via calcium influx, as indicated by the effects of thapsigargin and U73122. Second, denatonium induced an outward current across the cell membrane and not an inward current, as predicted by the phosphodiesterase hypothesis. The denatonium-induced response was not dependent on extracellular calcium; when the concentration of extracellular $\mathrm{Ca}^{2+}$ was reduced to zero, the denatonium still elicited a calcium response. Third, the denatonium-induced response was mediated via a G-protein; GDP- $\beta$-S blocked the denatonium-induced outward current. Finally, neither increases nor decreases in intracellular cAMP levels affected either resting $\left[\mathrm{Ca}^{2+}\right]_{\mathrm{i}}$ or the denatonium-induced response. In combination, these data support strongly the hypothesis that denatonium is transduced via an $\mathrm{IP}_{3}$-mediated rather than a cAMP-mediated pathway in mudpuppy.

There is evidence in rat and mouse that denatonium acts via the PLC- $\mathrm{IP}_{3}$ pathway. In rat, $\mathrm{IP}_{3}$ receptors and $\mathrm{Ca}^{2+}$-ATPase are found in taste buds of the circumvallate papilla, at their highest densities near the taste pore (Hwang et al., 1990). Denatonium enhances intracellular levels of $\mathrm{IP}_{3}$ in these cells, (Hwang et al., 1990), and $\mathrm{IP}_{3}$ depletes accumulated $\mathrm{Ca}^{2+}$ from intracellular stores in a dose-dependent manner (Hwang et al., 1990). Denatonium increases $\left[\mathrm{Ca}^{2+}\right]_{\mathrm{i}}$ in some rat taste cells (Akabas et al., 1988; Bernhardt et al., 1996). In mouse circumvallate and foliate papillae, denatonium activates PLC (Spielman et al., 1994b).

The concentrations of denatonium required to elicit calcium responses in mudpuppy taste cells were higher than those required to elicit calcium responses from rat taste cells (Akabas et 
al., 1988) or $\mathrm{IP}_{3}$ responses from mouse taste tissue (Spielman et al., 1994b). However, the concentrations were consistent with those reported to activate a denatonium receptor in bovine taste membranes (Ruiz-Avila et al., 1995). In addition, in behavioral studies, mudpuppies reject food pellets containing 1-10 mM denatonium after tasting them, suggesting that it is aversive to them (Ogura et al., 1996).

In mouse taste cells, another transduction pathway has been suggested for denatonium; activation of phosphodiesterase via the G-proteins transducin and gustducin (Ruiz-Avila et al., 1995). By analogy with phototransduction, phosphodiesterase reduces intracellular cAMP. This relieves a cAMP block of a cyclic nucleotidesuppressible cation channel and causes the cell to depolarize (Kolesnikov and Margolskee, 1995). This hypothesis is supported by the observation that transgenic mice, which lack gustducin, are less sensitive to denatonium (Wong et al., 1996). This model of bitter transduction was not supported by our data in mudpuppy. First, denatonium hyperpolarized taste cells; it did not depolarize them. Second, the denatonium-induced increase in $\left[\mathrm{Ca}^{2+}\right]_{\mathrm{i}}$ arose from intracellular release and not from influx through a cation channel. Finally, modulation of intracellular cyclic nucleotide levels failed to affect intracellular calcium levels, ruling out a direct effect of cyclic nucleotides on $\left[\mathrm{Ca}^{2+}\right]_{\mathrm{i}}$. Our evidence that intracellular cyclic nucleotide levels failed to affect the denatonium-induced response also rules out cyclic nucleotide modulation of the $\mathrm{IP}_{3}$ pathway in mudpuppy taste cells (Lindemann, 1996a).

The identity of the G-protein involved in denatonium transduction in the mudpuppy is moot. In mouse, sucrose octa-acetate, another potent bitter compound, acts via a PTX-sensitive G-protein such as $\mathrm{G}_{\mathrm{i}}$ or $\mathrm{G}_{\mathrm{o}}$ (Spielman et al., 1994b), but in mudpuppy, PTX failed to abolish the denatonium-induced response. We do not believe that the lack of effect of PTX resulted from an insufficient incubation period, because a similar incubation period was sufficient to demonstrate inhibition by PTX of a G-protein modulated calcium current in mudpuppy taste cells (Delay et al., 1997). These data suggest that a PTX-insensitive G-protein, such as a member of the $\mathrm{G}_{\mathrm{q}}$ family (Simon et al., 1991; Taylor et al., 1991), may activate PLC in mudpuppy taste cells. $\alpha$-Subunits of the $\mathrm{G}_{\mathrm{q}}$ family have been identified in mouse and rat taste tissue (Spielman et al., 1994a; Tabata et al., 1996). It has been suggested that the $\beta \gamma$-subunits of gustducin may activate PLC (Wong et al., 1996); however, because mouse gustducin has PTX-binding sites, it probably plays no role here. Gustducin has not been examined in mudpuppy. Additional experiments are necessary to determine which G-proteins could be responsible for the denatonium response in mudpuppy taste cells.

Although other bitter stimuli such as caffeine, strychnine, and sucrose octa-acetate activate PLC in mouse taste cells (Spielman et al., 1994b), not all bitter compounds are transduced via the $\mathrm{IP}_{3}$ pathway. Some bitter compounds, such as quinine and $\mathrm{CaCl}_{2}$, directly block the voltage-dependent $\mathrm{K}^{+}$channels that are located on the apical end of mudpuppy taste cells (Kinnamon et al., 1988b; Bigiani and Roper, 1991; Cummings and Kinnamon, 1992). These $\mathrm{K}^{+}$channels are open at rest, and blocking them causes depolarization. In mouse taste cells, denatonium also blocks voltage-dependent $\mathrm{K}^{+}$channels (Spielman et al., 1989), although the apical location of these channels has not been established for mouse. In mudpuppy, it is probable that taste cells may have both transduction pathways for bitter stimuli because $\sim 80 \%$ of cells responded to quinine and $\mathrm{CaCl}_{2}$ (Bigiani and Roper, 1991) and a similar percentage responded to denatonium.
It is not clear whether the mudpuppy can discriminate among these bitter taste stimuli. Behavioral studies show that most bitter stimuli are rejected by the mudpuppy (Bowerman and Kinnamon, 1994; Ogura et al., 1996). Because mudpuppies do not respond well to appetitive taste stimuli such as sugars, it is not surprising that most taste cells respond to bitter stimuli.

The $\mathrm{IP}_{3}$ pathway is not unique to bitter taste transduction, because it is activated in some mammalian taste cells by synthetic sweeteners (Bernhardt et al., 1996). Other sweet stimuli are transduced via an adenylate cyclase-cAMP cascade (Striem et al., 1991; Cummings et al., 1993, 1996; Kinnamon and Margolskee, 1996).

The final step in the $\mathrm{IP}_{3}$ transduction pathway is yet to be confirmed. In rat and mudpuppy taste cells, denatonium increases $\left[\mathrm{Ca}^{2+}\right]_{\mathrm{i}}$ by 50-100 nм (Akabas et al., 1988; Bernhardt et al., 1996; present study). Although this concentration has been suggested to lead to transmitter exocytosis from synaptic release sites (Akabas et al., 1988; Spielman et al., 1994b; Bernhardt et al., 1996; Kinnamon and Margolskee, 1996), this has yet to be demonstrated directly. Compared with these relatively small increases of $\left[\mathrm{Ca}^{2+}\right]_{i}$ in taste cells, neuroendocrine cells require at least $200 \mathrm{nM}$ (reaching a peak at $1 \mu \mathrm{M}$ ) for exocytosis (Augustine and Neher, 1992), whereas goldfish retinal presynaptic terminals require at least 50 $\mu \mathrm{M}\left[\mathrm{Ca}^{2+}\right]_{\mathrm{i}}$ (Von Gersdorff and Matthews, 1994). Total $\left[\mathrm{Ca}^{2+}\right]_{\mathrm{i}}$ rarely rose above $300 \mathrm{~nm}$ in any of the cells we tested. For technical reasons, the measured $\left[\mathrm{Ca}^{2+}\right]_{\mathrm{i}}$ may underestimate the true maximum at synaptic release sites, because we measured $\left[\mathrm{Ca}^{2+}\right]_{\mathrm{i}}$ over the center of the whole cell to avoid edge artifacts and may have missed contributions from synaptic release sites. Further, the true maximum may have been underestimated because of out-of-focus blur from above and below the image plane. Lindemann (1996b) has shown that peak transients of $\left[\mathrm{Ca}^{2+}\right]_{\mathrm{i}}$ in taste cells can be underestimated using fura-2, by factors of $>3$, unless deblurring algorithms are used to reduce the focal depth. In addition, the measured maximum $\left[\mathrm{Ca}^{2+}\right]_{\mathrm{i}}$ was usually the first measurement made after denatonium stimulation, and we may have missed the true maximum because of the slow time resolution of our system. Also, it is possible that the kinetics of calcium binding to fura- 2 may have influenced our ability to identify the true maximum $\left[\mathrm{Ca}^{2+}\right]_{\mathrm{i}}$ (Nowycky and Pinter, 1993). Finally, the data do not rule out the possibility that denatonium elicits calcium influx through the plasma membrane triggered by store depletion, as has been observed in several cell types (Striggow and Ehrlich, 1996). Such an influx could mediate large increases in $\left[\mathrm{Ca}^{2+}\right]_{i}$ near the membrane that might not be detected by the imaging system because of blurring of the signal. Nevertheless, the maximum increases in $\left[\mathrm{Ca}^{2+}\right]_{\mathrm{i}}$ observed here are similar to those observed in taste cells in rat and mouse in response to various tastants (Akabas et al., 1988; Bernhardt et al., 1996; Hayashi et al., 1996). This poses the interesting question of whether these levels of intracellular calcium are sufficient to cause transmitter release, because these levels are less than those necessary for exocytosis in neuroendocrine cells and neuronal presynaptic terminals. However, taste cells are neither neuroendocrine cells nor neurons and may not use the same mechanisms for exocytosis. For example, taste receptor cells lack synaptophysin, which is an integral transmembrane protein associated with synaptic vesicles of the size found in taste cells (Nelson and Finger, 1990). Therefore, the mudpuppy taste cell is a useful model in which to study this problem, because denatonium increases $\left[\mathrm{Ca}^{2+}\right]_{\mathrm{i}}$ without depolarizing the cell. Membrane depolarization could confound the analysis by increasing $\left[\mathrm{Ca}^{2+}\right]_{\mathrm{i}}$ locally at transmitter release sites. These studies are underway. 


\section{REFERENCES}

Akabas MH, Dodd J, Al-Awqati Q (1988) A bitter substance induces a rise in intracellular calcium in a subpopulation of rat taste cells. Science 242:1047-1050.

Augustine GJ, Neher E (1992) Calcium requirements for secretion in bovine chromaffin cells. J Physiol (Lond) 450:247-271.

Belitz H-D, Weiser H (1985) Bitter compounds: occurrence and structure activity relationships. Food Rev Int 1:271-354.

Bernhardt S, Naim M, Zehavi U, Lindemann B (1996) Changes in $\mathrm{IP}_{3}$ and cytosolic $\mathrm{Ca}^{2+}$ in response to sugars and non-sugar sweeteners in transduction of sweet taste in the rat. J Physiol (Lond) 490:325-336.

Bigiani A, Roper SD (1991) Mediation of responses to calcium in taste cells by modulation of a potassium conductance. Science 252:126-128.

Birnbaumer L (1990) G proteins in signal transduction. Annu Rev Pharmacol Toxicol 30:675-705.

Bowerman AG, Kinnamon SC (1994) The significance of apical $\mathrm{K}^{+}$ channels in mudpuppy feeding behavior. Chem Senses 19:303-315.

Burch R, Axelrod J (1987) Dissociation of bradykinin-induced prostaglandin formation from phosphatidylinositol turnover in Swiss 3T3 fibroblasts: evidence for $\mathrm{G}$ protein regulation of phospholipase A2. Proc Natl Acad Sci USA 84:6374-6378.

Chu A, Dixon MC, Saito A, Seiler S, Fleischer S (1988) Isolation of sarcoplasmic reticulum fractions referable to longitudinal tubules and junctional terminal cisternae from rabbit skeletal muscle. Methods Enzymol 157:36-46.

Cummings TA, Kinnamon SC (1992) Apical $\mathrm{K}^{+}$channels in Necturus taste cells. J Gen Physiol 99:591-613.

Cummings TA, Powell J, Kinnamon SC (1993) Sweet taste transduction in hamster taste cells: evidence for the role of cyclic nucleotides. J Neurophysiol 70:2326-2336.

Cummings TA, Daniels C, Kinnamon SC (1996) Sweet taste transduction in hamster: sweeteners and cyclic nucleotides depolarize taste cells by reducing a $\mathrm{K}^{+}$current. J Neurophysiol 75:1256-1263.

Delay RJ, Kinnamon SC, Roper SD (1997) Serotonin modulates voltagedependent calcium current in Necturus taste cells. J Neurophysiol, in press.

De Moel MP, Van De Put FHMM, Vermegen TMJA, De Pont JHHM, Willems PHGM (1995) Effect of the aminosteroid, U73122, on $\mathrm{Ca}^{2+}$ uptake and release properties of rat liver microsomes. Eur J Biochem 234:626-631.

Gilman A (1987) G proteins: transducers of receptor-generated signals. Annu Rev Biochem 56:615-649.

Goldsmith BA, Abrams TW (1991) Reversal of synaptic depression by serotonin at Aplysia sensory neuron synapses involves action of adenylate cyclase. Proc Natl Acad Sci USA 88:9021-9025.

Grynkiewicz G, Poenie M, Tsien RY (1985) A new generation of $\mathrm{Ca}^{2+}$ indicators with greatly improved fluorescence properties. J Biol Chem 260:3440-3450.

Hamill OP, Marty A, Neher E, Sakmann B, Sigworth FJ (1981) Improved patch-clamp techniques for high-resolution current recording from cells and cell-free membrane patches. Pflügers Arch 391:85-100.

Harris DN, Assad MM, Phillips MB, Goldberg HJ, Antonaccio MJ (1979) Inhibition of adenylate cyclase in human blood platelets by 9-substituted adenine derivatives. J Cyclic Nucleotide Res 5:125-134.

Hayashi Y, Zviman MM, Brand JG, Teeter JH, Restrepo D (1996) Measurement of membrane potential and $\left[\mathrm{Ca}^{2+}\right]_{i}$ in cell ensembles: application to the study of glutamate taste in mice. Biophys $\mathbf{J}$ 71:1057-1070.

Hwang PM, Verma A, Bredt DS, Snyder SH (1990) Localization of phosphatidylinositol signalling components in rat taste cells: role in bitter taste transduction. Proc Natl Acad Sci USA 83:7395-7399.

Kinnamon SC, Margolskee RF (1996) Mechanisms of taste transduction. Curr Opin Neurobiol 6:506-513.

Kinnamon SC, Roper SD (1988) Membrane properties of isolated mudpuppy taste cells. J Gen Physiol 91:351-371.

Kinnamon SC, Cummings TA, Roper SD (1988a) Isolation of single taste cells from lingual epithelium. Chem Senses 13:355-366.

Kinnamon SC, Dionne VE, Beam KG (1988b) Apical localization of $\mathrm{K}^{+}$ channels in taste cells provides the basis for sour taste transduction. Proc Natl Acad Sci USA 85:7023-7027.
Kolesnikov SS, Margolskee RF (1995) A cyclic-nucleotide-suppressible conductance activated by transducin in taste cells. Nature 376:85-88.

Lindemann B (1996a) Chemoreception: tasting the sweet and the bitter. Curr Biol 6:1234-1237.

Lindemann B (1996b) The amplitude of $\mathrm{Ca}^{2+}$ transients elicited in taste receptor cells responding to sweet stimuli. Chem Senses 21:278.

Meyer T, Stryer L (1990) Transient calcium release induced by successive increments of inositol 1,4,5-trisphosphate. Proc Natl Acad Sci USA 87:3841-3845.

Nelson GM, Finger TE (1990) Localization of synaptophysin immunoreactivity in rat lingual tissue. Chem Senses 15:609-610.

Nowycky MC, Pinter MJ (1993) Time courses of calcium and calciumbound buffers following influx in a model cell. Biophys J 64:77-91.

Ogura T, Bowerman AG, Mackay-Sim A, Kinnamon SC (1996) Responses of mudpuppy taste receptor cells to denatonium: $\left[\mathrm{Ca}^{2+}\right]_{\mathrm{i}}$, ionic current and feeding behavior. Chem Senses 21:651.

Ruiz-Avila L, McLaughlin SK, Wildman D, McKinnon PJ, Robichon A, Spickofsky N, Margolskee RF (1995) Coupling of bitter receptor to phosphodiesterase through transducin in taste receptor cells. Nature 376:80-85.

Salari H, Bramley A, Langlands J, Howard S, Chan-Yeung M, Chan H, Schellenberg R (1993) Effect of phospholipase C inhibitor U-73122 on antigen-induced airway smooth muscle contraction in guinea pigs. Am J Respir Cell Mol Biol 9:405-410.

Sharp AH, McPherson PS, Dawson TM, Aoki C, Campbell KP, Snyder SH (1993) Differential immunohistochemical localization of inositol 1,4,5trisphosphate- and ryanodine-sensitive $\mathrm{Ca}^{2+}$ release channels in rat brain. J Neurosci 13:3051-3063.

Simon MI, Strathmann MP, Gautam N (1991) Diversity of G proteins in signal transduction. Science 252:802-808.

Simpson PB, Challis RAJ, Nahorski SR (1995) Neuronal $\mathrm{Ca}^{2+}$ stores: activation and function. Trends Neurosci 18:299-306.

Spielman AI, Mody I, Brand JG, Whitney G, MacDonald JF, Salter MW (1989) A method for isolating and patch-clamping single mammalian taste receptor cells. Brain Res 503:326-329.

Spielman AI, DeMyer S, Turner G, Brand JG (1994a) Immunohistochemical localization of G-proteins in mouse taste buds. In: Olfaction and taste XI (Kurihara K, Suzuki N, Ogawa H, eds), p 82. Tokyo: Springer.

Spielman AI, Huque T, Nagai H, Whitney G, Brand JG (1994b) Generation of inositol phosphates in bitter taste transduction. Physiol Behav 56:1149-1155.

Striem BJ, Naim M, Lindemann B (1991) Generation of cyclic AMP in taste buds of the rat circumvallate papilla in response to sucrose. Cell Physiol Biochem 1:46-54.

Striggow F, Ehrlich BE (1996) Ligand-gated calcium channels inside and out. Curr Opin Cell Biol 8:490-495.

Sutko JL, Ito K, Kenyon JL (1985) Ryanodine: a modifier of sarcoplasmic reticulum release in striated muscle. Fed Proc 44:2984-2988.

Tabata S, Crowley HH, Kinnamon JC (1996) Immunocytochemistry of $\mathrm{G} \alpha 14$ in taste cells of the rat. Chem Senses 21:679.

Taylor R, Roper S (1994) $\mathrm{Ca}^{2+}$-dependent $\mathrm{Cl}^{-}$conductance in taste cells from Necturus. J Neurophysiol 72:475-478.

Taylor SJ, Chae HZ, Rhee SG, Exton JH (1991) Activation of the $\beta 1$ isozyme of phospholipase $\mathrm{C}$ by the $\alpha$ subunits of the Gq class of G-proteins. Nature 350:516-518.

Thastrup O, Cullen PJ, Drobak BK, Hanley MR, Dawson AP (1990) Thapsigargin, a tumor promoter, discharges intracellular $\mathrm{Ca}^{2+}$ stores by specific inhibition of the endoplasmic reticulum $\mathrm{Ca}^{2+}$-ATPase. Proc Natl Acad Sci USA 87:2466-2470.

Thayer SA, Perney TM, Miller RJ (1988) Regulation of calcium homeostasis in sensory neurons by bradykinin. J Neurosci 8:4089-4097.

Thompson AK, Mostafapour SP, Denlinger LC, Fisher SK (1991) The aminosteroid U-73122 inhibits muscarinic receptor sequestration and phosphoinositide hydrolysis in SK-N-SH neuroblastoma cells. J Biol Chem 266:23856-23862.

Von Gersdorff H, Matthews G (1994) Dynamics of synaptic vesicle fusion and membrane retrieval in synaptic terminals. Nature 367:735-739.

Wong GT, Gannon KS, Margolskee RF (1996) Transduction of bitter and sweet taste by gustducin. Nature 381:796-800. 